\title{
10. HUMAN RIGHTS VS. CUSTOM IN THE PACIFIC: STRUGGLE, ADAPTATION, OR GAME?
}

\author{
By: Ian Fraser
}

\section{KEY TERMS AND PHRASES}

\section{Analogy}

The comparison of one item with another, suggesting that they are alike in some relevant way. In the common law analagous reasoning is the extension of a rule derived from a precedent to a different factual situation, by arguing that the new situation is relevantly similar to that of the precedent.

\section{Aspiration}

An aspiration is a wish to achieve, or attain, some state or condition. A constitution's aspirational element may be a unified, prosperous, and orderly society.

\section{Discrimination}

To discriminate is to differentiate among things, or people, in order to treat different categories of those things or people differently. Every statute and every legal decision does this, of course, but as normally used in the law the meaning of the term is more specific. It describes discrimination which is unjustified or unlawful. (A government does not discriminate when it issues passports only to its citizens, but it is discriminating when it issues passports only to male citizens.)

\section{Globalisation}

The growing standardisation of any of a number of activities and values across countries and cultures. Most commonly, the expansion of developed world, especially American, economic practices to the rest of the world.

\section{Idealisation}

The conception that for every phenomenon in the world there is a perfect model, or archetype, of which the actual phenomena are merely imperfect examples. One could say marriage is often idealised as a loving, complete, and permanent union, even by people who have never known a real couple who lived so. This way of conceiving of reality has great power in Western philosophy.

\section{Ideology}

A set of beliefs which is internally consistent, forming the basis of a person's outlook on life or some aspect of life. (The term is usually used to refer to beliefs about politics and political issues.) 


\section{INTRODUCTION}

I propose here a scheme for considering what is going on when, in argument about a government policy or decision, some people invoke 'human rights' (or 'constitutional rights') to justify their views and other people, opposing them, invoke 'custom' (or 'tradition'). Such arguments may be political contests within a government's own bureaucracy, or in Parliament, or academic debates in pages like these or in university cafeterias, or legal submissions to courts of law or law reform bodies, or popular disputes in editorial pages, over kitchen tables or under village trees. I propose a scheme, a set of models, for thinking about the patterns that these arguments assume whatever their setting.

The models emphasise what is distinctive about the different views one can take. This will accurately reflect what is going on in some instances of the arguments. For others, it might seem to be exaggeration, a most un-Pacific focus on difference, on the implications or assumptions of what a person says, or believes. But the aim here is clarity in observation, not viable tactics for resolving disputes. (Those, one hopes, are fostered by clear perception.) We, as students of the South Pacific, are observing events, and observers need categories to make sense of what they see - it helps to have lobsters and true crabs in mind when studying coconut crabs - and what follows, I think, helps understand this field of study.

\section{The scheme: struggle, adaptation, game}

This is not a purely legal view. From a legal point of view, the issue is simple if considered in the abstract - yet in any concrete case it is complex, too complex to yield even a narrowly legal answer.

The simplicity lies in the hierarchy of laws, the first thing any student of law learns, in the Pacific or elsewhere. The constitution is above all other law in the sense that if any conflict arises between it and what some other 'law', or source of law, seems to say then the constitution prevails. At the same time it is below all law, in the sense that all lawful acts and decisions must, however indirectly, be based on it. It is the foundation of law, the only set of rules and principles whose validity does not depend upon some other set of legal rules and principles. It just is: it is that it is, to invoke a Biblical, and so quite apt, analogy (as I shall argue). So, 'in principle', legal principle, the answer to any question involving the legal powers, disabilities, rights, privileges, or prohibitions of anyone or any authority is simple. The law's answer is whatever the constitution says. If that accords with the 'rights' side, that side wins; if it accords with the 'tradition' side, that side wins. This marvellously straightforward approach to otherwise thorny issues is the very point of the movement for - originally an idealistic dream of - written constitutions. ${ }^{1}$

The complexity, of course, lies in the second thing any student of law learns. The same set of words may quite legitimately mean different things to different people. That is, one can disagree with someone else about what a set of words, including a provision of the constitution, should mean (should be 'held' by a court to mean), 
while admitting that the other interpretation is a possible, or plausible, one. It is just that more than one plausible interpretation exists, especially as the words are applied to any particular set of circumstances. Further, in any given set of circumstances, one finds that others do not necessarily share the interpretation one would prefer. At that point everyone is agreed that the constitution should prevail: yet there is no agreement on what should actually be done. Should the constitution mean what the words it uses are held to mean in foreign jurisdictions? Should it mean what one thinks 'the people' would read it to mean? If it reiterates rights in terms shared by international and foreign bills of rights, as all the Pacific constitutions do, but also expresses an adherence to the traditional values of its place - as all Pacific constitutions also $\mathrm{do}^{2}$ - can its true meaning be that one prevails over the other?

An example is the recurring issue in Melanesian jurisdictions of migrants settling on land to which they have no title, near capital cities, who become perceived by more secure residents of those cities as labour pools for criminal gangs. Since before independence in Papua New Guinea, since the early 1980s in Solomon Islands, and by the end of last century in Vanuatu, proposals have been regularly thrown up by the press and politicians to 'send the squatters back home'. Just as regularly they are met by the objection that this would violate the squatters' rights. The legitimacy of kicking the miscreants off rightful owners' land lies in custom. Village leaders in the squatters' home areas should take responsibility for their people and make them return. The legitimacy of letting the citizens stay where the opportunities are lies in the rights granted by the constitution: they share everyone's right of movement within their country, they share everyone's liberty from arbitrary seizure. The debate assumes that form, and then it freezes. (If action does follow, it is a matter of sheer force: bulldozers in PNG, militias in Solomon Islands.)

Should we regard this suspended argument as the legal aspect of a political struggle, in which the concept of rights is a weapon, whose wielders face opponents armed with the concept of custom? I shall consider this view first; it is the closest to what would seem to be the orthodox or mainstream analysis. Legal argument is imagined litigation, which is politics by other means. Like Clausewitz' view of war, this is an idealisation of law - in his terms, 'true' law - law as the pursuit of judicial orders in accordance with correct norms. ${ }^{3}$ In this model, what is going on is a struggle (or set of struggles) to accomplish some social or economic end(s), in which the struggling parties attempt to use legal concepts against each other. As observers we should examine the actual use and effectiveness of these concepts, imagine how they might be used and applied, and consider how they could be improved.

But perhaps that model assumes too much rationality in the people, and groups of people, we are observing. Perhaps they are not so calculating and goal-oriented. Law, like war, is not always resorted to as a rationally chosen means to an end. It could be that the concept of rights is attractive to people for reasons other than practical utility: that they are drawn to it not because they have decided that it will help them achieve some goal, but because of some less rational kind of attraction. Perhaps the attractive quality is not so tangible. Perhaps it represents a moral good to them. Perhaps they 
do not really choose to invoke it at all. Perhaps the concept of rights, in a sense, chooses them - the sense being that the concept, in a way more familiar when we are observing fashions, religions, or consumer preferences, spreads and 'catches on' as though it were alive and people were its environment.

In this model, my second, what is going on is competition between ideologies, 'rights' representing one and 'custom' another. The competition may be conscious, played out in the hearts and minds of the people observed, the subject of deliberate debate; this is the first version of the model. I shall call it the moral version. Or it may be more like natural selection in an ecosystem, played out indeed in hearts and minds but not by those hearts and minds. It could be that the competition is of the attractiveness of concepts, without people being conscious of what attracts them. This is the second version. I shall call this the evolution version. Both versions emphasise the ways a concept can be adapted to its environment.

Finally, perhaps both the above models involve being misled by appearances. Perhaps, in the reality the models are intended to describe, rights are not 'taken seriously' any more than communism and anti-communism were in, say, 1980s Africa. It could be that 'human rights' is a mask, a rhetorical device to conceal manoeuvres and motivations quite unconnected to the concept itself - the playing of a game. One could see it as a misleading label, stuck onto legal policies which really amount to no more than a continuation of the colonial heritage - the commercially-oriented individualism and freely-alienable property rights that were once labelled 'civilisation' or 'progress'. A corporation, for example, could resist regulation of advertising in the name of 'freedom of expression'.

In this third model what is going on is forces for Western-style development making the associated legal policies more palatable to local people. But one could also see the intended audience as external. This generates another version of the third model. In it, what is going on is local people, especially in government, putting on 'human rights' as a team uniform, showing the international sources of aid, loans, and legitimacy that they are on the same side. What the real manoeuvres and motivations are is arbitrary in relation to the concepts of 'rights' and 'custom'. Those concepts, as in the version described in the paragraph above, are used as labels, but the labels have no relation to the policies they label - like the colours of sports-team uniforms.

What follows, then, is the consideration of several different ways of observing, and thinking about, the significance and relative success of rhetoric about rights and rhetoric about custom in the modern South Pacific. Note that although the rights concept is generally associated with the former colonial powers, it includes notions of collective rights, especially national self-determination and the importance of indigenous status, which are not necessarily of the colonial heritage. Note too that although the custom concept is associated with the quality of being indigenous, its rhetorical deployment generally borrows a great deal from foreign example and nonindigenous institutions (within the region and beyond it). Legal and academic writers advocating the use of custom borrow freely from African literature and Colonial authorities created major custom institutions like the Land and Titles Court in Samoa 
and the (Great) Council of Chiefs in Fiji Islands. There is no purity in culture. Human affairs are rarely simple. Clarity can only be relative.

\section{STRUGGLE? THE MANA OF HUMAN RIGHTS}

It is beyond question that as interpreted in developed world bills of rights a right of movement means that people may not be 'sent back' to their home areas, even if ejecting them from others' land is permissible. Likewise, even the bare right of liberty is incompatible with a chief, or village authority however constituted, ordering a person to live in one place rather than another. The point is simply not arguable such an order would not be valid even if authorised by a duly enacted statute. It is equally beyond question that village authorities could, in custom, order people of their village to live here or there. ${ }^{4}$ This too is not an arguable point - in its context. But in the developed world context land is only property and any association between kinship and locality means very little, and in the customary context people of the village lived in the village. (Because people lived with their leaders, the leaders' power was less autocratic than it might seem when described abstractly.) But the context of modern 'settlements', whether in Port Moresby, Honiara, or Port Vila, is neither of these. This is what leads to the stalemate in argument. Each side is grasping at a branch that has no tree.

Yet each side, if skillful enough advocacy is employed, has a perfectly good legal argument. Each truly does rest on constitutional principle. The constitutions themselves are sufficiently 'flexible' (that is, vague) to support either side in any such issue. This is, notoriously, a feature of constitutions generally. It is crystallised in the Pacific by the explicit recognition of custom as a source of law. Beyond the Pacific, and in particular in the jurisdictions from which Pacific law is derived, a similar complication is expressed, in courts and in popular debate, by appeals to 'common sense', 'community values', or 'the ordinary person'. Within the Pacific courts lump those things together as a distinct source of law called 'custom'. Here too, of course, they really are law for all practical purposes, for the majority of the population. ${ }^{5}$

Here in the Pacific, that is, constitutional rights are not the 'trump' they are seen to be in Western jurisdictions: the top-value card that beats any card drawn from ordinary statute or common law. Nonetheless they are, in law, strong bases of argument. Is that status, their force as the basis of argument in law, the reason that people use them in argument generally? Are they attractive because they are seen to carry mana, the quality of someone whom others choose to obey (or, time before, a victorious warrior)?

If one thought so then one would have to say that people do intend to achieve ends 'in the real world', outside the courtroom, by invoking rights. In the squatter example it would mean those who advocate letting the squatters stay think that that is what the government will do if they can persuade it, or the courts, that that is what the squatters' rights entail. The power of rights may be restricted to actual litigation, or it may be more general, a mana to which public or elite opinion responds, even outside courts of law. If it is that kind of general mana then it would follow that if 
the public or the elite is persuaded that the law requires a course of action there will be support for that course of action. In other words, this model of rights as weapons entails the belief that the law itself is effective in causing events outside the legal system - or at least that rights-advocates believe this. Is that justified?

We could consider it justified if there were examples of such impact, comparable to the history of rights-advocacy in other jurisdictions. In America successful rights arguments contributed crucially to ending official racial segregation and enabling access to legal abortion. In Canada they changed the procedures by which refugees are recognised and criminal suspects are investigated. In the UK they cut down the government's immunity to negligence suits. The legal sources of the rights arguments varied, from constitutional bills of rights in North America to common law in Australia and treaties in New Zealand and the UK. But in each jurisdiction it is the legal force of claims of right that created these changes. One should not exaggerate. One should note, especially, that all of these changes are most clearly changes within the legal system, whose precise effects on action outside it are much less obvious. But that there are actual effects, often as dramatic as legitimising 'settlements' would be, is indisputable.

Are there such stories in the Pacific jurisdictions? The rights are there in a legal sense. The issues are there in society, including, rather prominently, ones of discrimination, women's security and police powers. Rights arguments have been addressed to courts about political and religious discrimination in Samoa and about police powers in PNG, to take two examples. In deciding that matai were not accorded a constitutionallyentrenched preferential franchise, however, the Samoan court relied on interpreting the constitutional provisions relating to the franchise, avoiding decision on the relevance of a right to vote among non-matai. ${ }^{6}$ Papua New Guinean courts did create a line of decisions excluding evidence from criminal trials for police violation of suspects' rights, although they relied on the common law as much as the rights per se. They created another line awarding damages to village people illegally raided by the police, although these decisions emphasise the common law even more. ${ }^{7}$ In neither area, however, is there much sign that police conduct has been affected.

As one can question the precise reality of the rule of law in the Pacific, especially in the large Melanesian countries with their shrinking public services, so one can doubt this first model. Certainly courts of law are not the preferred forum for debating, much less settling, issues which seem to concern human rights - indeed, courts are rarely so used at all. In Fiji Islands and Solomon Islands the effective installation of unconstitutional governments in 2000-2001 has left the notion of a rule of law with only a precarious role in public affairs.

Is this then a likely model? It may describe what some people mean, although probably not many who are not lawyers. As a general view it does seem strained. ${ }^{8}$

\section{ADAPTATION? THE FITNESS OF HUMAN RIGHTS}

The inspiration for this model is the inevitable analogy between human rights and Christianity. Both are originally foreign notions. The potential local applicability and 
actual local incompatibility with existing practices of human rights, today, are both obvious - but three to six generations ago the same could have been said of Christianity. Christianity undeniably 'succeeded'. Did it succeed because it could be used effectively by people who wanted to accomplish something - because, when people worshipped in the appropriate way, things happened 'in the real world' which otherwise would not have happened? Christianity is strikingly dominant in Pacific culture, popular and official. Is this due to God responding to Christian prayers, as one might say the equally striking prevalence of rights-talk in the West is due to courts responding to rights-arguments and other institutions responding to courts?

The question cannot be answered precisely as put, of course. And there are many who would say it is not even the kind of question appropriate to a text examining legal and political affairs, especially if the approach is critical or sceptical. But then there are many, too, who would say the same of questions about human rights ideals. These too have their believers, people who consider human rights ideals beyond criticism (whatever arguments one may have about implementation). Both sets of people, insofar as they exist in the Pacific, are among those we are observing here; as observers we should ask not just whether we agree with them but also why they believe what they do.

In this model, the answer is 'no' (at least to the question precisely as put). Even if one reason why Christianity was so widely and thoroughly adopted was that it worked, in an instrumental sense, that does not seem to explain why the concept of human rights is as attractive as it is. This is the conclusion reached about the first model. The analogy is rather with another reason Christianity succeeded. In this model, human rights and Christianity are indeed analogous, and understanding the appeal of one helps understand the appeal of the other, but the analogy is in features of the ideas - 'human rights', and 'Christianity' - rather than their instrumental effectiveness in making things happen in politics.

Why was Christianity so attractive when it arrived? It was not instantly successful, of course. On many islands besides one near that from which I write, Erromango in Vanuatu, it was not the ideas of the very first missionaries that were first swallowed. In some places it only took real root once the local leadership decided, on personal and, quite likely, instrumental grounds, that people would have to adopt it, while in others missionaries struggled for a time with local authorities. But, fairly rapidly everywhere, Melanesian and Polynesian people found in Christianity some quality or feature which made it 'applicable and appropriate' to their lives (in the phrase used by constitutional drafters as a test for adopting foreign law), despite the fairly radical adjustment to behaviours that it meant.'

It was a great variety of particular doctrines of Christianity that were adopted, although in the usual particular village there was a consensus as to what sort of 'Christianity' the people would adopt. There seems to have been no great theological, as opposed to political, debate concerning the choices. One could conclude that it was some general quality or feature of Christianity as such which was 
attractive, rather than anything specific enough to distinguish, say, Catholicism from Lutheranism.

These points suggest two things for the model being proposed here. One is that it is something in the general idea of human rights, too, rather than any particular application of it that is attractive..$^{10}$ This is a strong point and, I argue, a valid analogy, to which I shall return. It is at the base of the evolution version of this model. The other is the relation of the imported idea to other changes. Christianity, of course, did not arrive anywhere alone; it came in association with other things - especially material improvements and opportunities which threatened tradition, disaster in the form of new diseases and the sheer fact of dramatic change, largely out of the people's control, in itself. People were not entirely passive, of course, but many of the changes must have felt like impositions. Becoming Christian would have meant many things, but one of them, and surely one of the more significant, was joining 'the modern world' in a way that was chosen.

And why chosen with such enthusiasm? Perhaps because in Christianity people saw a form of modernisation which promised something good in itself. The other forms of modernisation - material change and dependence and overturned political order were to be reluctantly accepted either to avoid worse, like submission to new political powers, or to try to obtain something desirable while minimising the cost, like selling labour or land (or sending children to school).

In the moral version of this model, what is attractive about human rights now is the same thing that was attractive about Christianity then. The concept offers a morally good quality to modernisation. The worth of modernisation is ambiguous, and in any event largely instrumental, whether it is called 'civilisation', 'development', or 'globalisation'. Development, now that the distribution of wealth following political independence is over, can seem as threatening as the disease and arbitrary rule that modernisation first brought a century ago. Religion gave a moral face to that first globalisation, which presaged colonialisation. Perhaps human rights represent the moral face of the current globalisation, which replaces government largesse with economic 'discipline'. Championing human rights finds in this process something to welcome precisely not because of what it can accomplish, but because it is good in itself.

This requires accepting that people do see something morally good in human rights and that they saw something morally good in Christianity. As it would have been several generations ago, it still is today a valid argument in the Pacific to say squatters should not be abused because that would be un-Christian: we are equally God's children, called to love all our fellows. Is there something similar going on when people say squatters should be better treated because they have a human right (or a constitutional one) to such better treatment? Do people affirm this because it affirms the moral equality of human beings (or of citizens)?

Perhaps they do. Perhaps the concept of rights has come to symbolise a modern morality, appropriate to this post-independence era of constitutions and globalisation, 
just as Christianity did during its initial era here. But why this would be is not obvious. Of course Christianity includes love for fellow human beings, an account of why we exist and a promise to reward virtue: but so do other religions, including the traditional ones it replaced. ${ }^{11}$ Likewise, the concept of human rights includes many very strong notions of the morally good, but so do the traditional concepts making up custom. The second, evolution, version of this model focusses one's view on why human rights would be seen to be 'good'.

Ideas are often said to 'have a life of their own', and in a useful sense this is more than a figure of speech. The useful sense is that they can spread, and evolve, in a way closely analogous to living species; and sometimes considering them in this way can explain their adoption better than an assumption that people consciously and rationally choose what to believe. It is not necessarily a radically different point of view. It is an emphasis on ideas themselves, when considering their relation to the people holding them. Religion has been the usual object of this view; few religious people, after all, choose their religion - the overwhelming majority of human beings, including those who believe very devoutly, profess the religion their parents professed. Having secured a niche in one generation's minds, the ideas of the particular faith spread naturally through parental authority to the next generation. Likewise, naturally, the great majority on the global scale of those who support the idea of human rights are offspring of parents who supported that idea. It is the changes that require explanation - why is there sometimes a pattern of people adopting a set of ideas that come to them horizontally, so to speak, from beyond their community?

In the case of religions, such patterns coincide with social upheaval. Faced with a greatly disruptive force, people tend to shift their adherence to a faith compatible with a way of dealing socially with that force. ${ }^{12}$ This is consistent with the account above of Christianity's reception in the Pacific: it seemed a good morality because it was a morality compatible with accepting the disruptions of modernisation. Naturally enough, given its long residence in Europe, Christianity was better adapted to the 'modernising' environment than were the old beliefs; and this was true of all the particular denominations of Christianity that Pacific islanders embraced.

Do we see something similar going on with the appeal to human rights today? Consider our example. Do people find it easier to acknowledge the unpleasant side of modernisation, in our example the slum-like settlements, by asserting a more benevolent side of that same modernisation - the notion of rights based policies? Do these go together as aspects of the same times? Given the way so many of the changes in Pacific society are provoked by events and decisions occurring outside the region, modernisation could seem a matter of space as well as of time. Could we say, even on matters of morality and social policy: as foreign problems take root here, so we treat them with foreign tools? This does seem plausible. Human rights, today, could seem morally good because as a set of values it is compatible with the disruptive forces of today. Human rights, that is, as a species of idea competing with custom for the same 
ecological niche, is naturally better adapted to the ways society is changing in the Pacific.

One can trace the compatibility - the adaptive features of this species of ideology more specifically. Especially as compared to custom, the human rights concept opens up several useful ways of thinking to its adherents. It allows one to accept change, to justify subjection to the market and government rather than to chief and family, to welcome the 'westernising' element of modernisation and to accept identity as citizen (or even just human) rather than as member of a personally known group. Most importantly in the Pacific, it can allow one to experience individualism as liberty rather than isolation, as independence rather than selfishness. ${ }^{13}$

\section{GAME? HUMAN RIGHTS AS TEAM COLOURS}

Finally, there is a model that notices a significance of human rights different from both their legal utility and their content. This is their symbolic value. By attaching human rights labels to them one can justify policies, and even judicial rulings, which are no departure from colonial policies and judgments. They thus seem modern, even progressive, without changing. Similarly, but more shallowly, one can invoke human rights as a general flag of convenience, indicating to the outside world that the government is on side - part of the human rights team of nations.

There was a project, in the independence era, to generate a new kind of law, a combination of the colonial heritage and indigenous tradition - Melanesian, or Pacific, rule of law. ${ }^{14}$ Much of it was included in independence constitutions, in the aspirational invocations of tradition with Christianity (as discussed above at note 2). It has not been seriously pursued since those times, despite the constitutional mandates. When 'the law' notices custom, it does so as something other than true law - either as fact, like 'compensation' treated as part-payment of damages or as a factor in sentencing, ${ }^{15}$ or as foreign law, like customary marriages. Custom is objectified and so kept out of the development of local common law.

The human rights label could justify this rejection of custom as a source of legal norms. Fault in negligence, say, or mens rea in criminal law, could be justified as manifestations of liberty rights. The general individualism of common law doctrine could be justified as reflecting the same philosophy in human rights. One would then be rejecting custom because it did not adequately protect liberty, or because its sense of 'liberty' was insufficiently individualistic. The new label could be better received than the old one, which was the 'civilisation' of the metropolitan country. After all, it amounts to no more than a simple claim to cultural superiority. There seems little sign of this thinking, however, even where the colonial era 'civilisation' mission is doubted. It does not seem to be what is going on, although an observer might look for it in the future.

The other version of this model is the most obvious, and the most cynical. Declared to an audience of foreign donors or development partners, a governmental or NGO commitment to human rights signifies willingness to join the team - like anti- 
communism 20 years ago or 'good governance' in our day. There is obvious advantage to this and it would not necessarily be illegitimate for any such body to seek that advantage. It must then be considered whether at least some of the talk of human rights we witness actually means very little, in itself - like a sports team's choice of colours.

What does matter is how easily the audience is satisfied that the government, or $\mathrm{NGO}$, is indeed on the human rights team. Are such declarations of policy (including the signing of treaties and enactment of legislation, on the part of governments) perceived as sufficient? As a case to observe on this point, consider, as it develops, the various governments' commitment in the Biketawa Declaration to supporting human rights in each other's jurisdictions, declared at the October 2000 Pacific Islands Forum meeting in Kiribati. Have governments issued any public comments on the human rights situations in other island countries? Has there been resentment of such comments? Are there any signs that diplomatic, trade, or other inter-governmental relationships are affected by human rights concerns?

\section{CONCLUSION}

The models proposed here are meant to assist observation, as tools of description. But does their consideration lead to any prescriptive conclusions about how we should react to the ways human rights are invoked?

In the jurisdictions most familiar with rhetoric about rights (notably, the United States of America) there has been much debate about the political and ideological effects of 'rights-talk'. After all, claiming a right to do something, or to resist someone doing something to one, is not the only way to those ends in any political or legal context.

The rights-claim appeals to law, but it is not the only source of standards of behaviour. Within law it appeals to a particular set of legal standards, usually constitutional ones. The common law and the statutory law offer other legal standards. The differences are not just in content but also in the form of the argument: emphasising analogy and authority in common law claims, textual sense in statutory ones, and broad statements of value in constitutional ones. Religion, tradition, professional ethics and a community's morality, in contrast, offer non-legal standards.

When I claim a right to freedom of expression to justify my writing something critical of a government I have chosen a particular form of justification. Instead of appealing to the heritage of open debate in village councils, the Bible, the idea of academic freedom or a community's tradition of tolerating such criticism, I have invoked the law. And within law I have appealed to rights, constitutional or human rights, as opposed to the common law civil liberties (or some particular authoritative decision) and to applicable legislation.

Noticing that invoking 'rights' involves such a choice, and asking why it is made, has led many thinkers to conclude that people often — and perhaps usually — do not 
realise just what choice they have made, or its implications. And the implications are not necessarily - are perhaps not even usually - favourable to the people who invoke rights. Rights become 'reified' in people's thinking: they distract them from what is occurring in the real world. They commit people to the legal system as opposed to political struggle. In litigating claims in the legal system the advantage is always with the already privileged who have the money for lawyers and the education to use them. And democracy does not rule in a courtroom. Rights direct a political movement's resources to managing and paying for lawyers, rather than organising and leading people. These points are known as 'the rights critique', associated with leftist white academics in the 1980s. ${ }^{16}$

On the other hand, invoking rights can serve as a rallying point around which to organise popular movements. Succeeding in a rights-claim, even just in the courtroom, can be experienced as empowering. And for some people, small or nearly powerless minorities, political struggle is simply not a viable option. Rights (that is, legal struggle) offer them their only hope of improvement. People likely to become criminal accused are the ones most likely to benefit from rights-arguments in court as opposed to political pressure, since they do not constitute any politician's constituency; squatters are in a similar position. These points are known as the critique of the rights-critique', associated with a later (1990s) generation of racialand sexual-minority academics. ${ }^{17}$ The debate has not noticeably moved beyond these platforms, although, as a cause, human rights have certainly advanced: most notably, for Pacific jurisdictions, in New Zealand and the UK. ${ }^{18}$

That debate is premised on the potency of rights as a weapon in litigation, the first of my models here. It is premised too on a Western social context, where community feeling is elusive, individualism is embedded in popular ideology, and government is experienced as an all-powerful professional bureaucracy. Does this limit the debate's relevance in the South Pacific? The obvious relevance is limited to the point, in the rights-critique, of reliance on rights draining resources to lawyers and, on the other side, the point that a right can be an effective rallying cry (as it is used in Pacific women's movements).

Perhaps, however, the basic ideas of the critique could acquire relevance as - or if human rights gain momentum as a cause. Rights are a distraction from other means to achieve political ends. To the extent that people trying to achieve political ends by invoking rights assume that custom is something they must overcome, they allow the impression that they oppose the values associated with community and tradition. This is a drastic, even fatal, concession to make; few people want to see themselves as throwing away tradition. In the West, this was an argument of the rights-critics: if in using rights-claims to achieve progressive ends we give the impression that we oppose tradition and community, then our conservative opponents will be able to portray themselves as the defenders of these values. We may, for example, support more rights for women, in order to achieve safer and healthier family life, but if this is seen as an attack on all the traditional roles of women the conservatives will be able to say they are the guardians of 'family values'. ${ }^{19}$ 
Reliance on rights to justify one's claims involves reliance on law, immediately or by logical entailment, displacing perhaps a more appropriate reliance on garnering popular support. This can be an error even where, legally, rights really are 'trumps'. Observing a gathering responsiveness to human rights talk, if that is what we see in the future, we should not necessarily be congratulatory of the rights proponents.

But all of the above, again, takes rights as weapons, a particular kind of tool, rationally (if not necessarily wisely) chosen to suit the job. If my second model is valid, however, these observations miss the point. Rights-talk will gain in power whether it is rationally effective or not - rhetorical power, in public discussion (which may or may not move courts of law). It will be swept along as the current form of modernisation gathers force.

If we see the third model gain plausibility, governments and NGOs associating themselves with rights purely as team colours, will that affect the attractiveness, or adaptiveness, of rights-talk among people? And if so, what sort of custom-talk will that development favour?

It may be a combination of the second and third models that proves most apt. If, on the custom side, one focusses on the role of 'chiefs', the rights side can be seen as an alternative. To some extent this is co-evolution of the very old dichotomy - or dualism, in legal terms - of traditional/modern, indigenous/introduced. Those terms are losing cogency as chiefhood develops, and indeed as originally-foreign legal and political influences are internalised in Pacific societies (as religious ones were so long ago).

It seems clear now that the role of chiefs is in large part to mediate modernisation. ${ }^{20}$ The independent state appeared previously to almost all of its people, in most of the Pacific, as a source of largesse. This significance is passing. In its wake, the phenomenon of chiefly power represents a mobilisation of local solidarity. Rightstalk, seen in this light, constitutes an alternative way to try to integrate the realities of modernisation: mobilising international solidarity. 


\section{ENDNOTES}

1 See the chapter on the Civil Tradition in Glenn, H. P. 2000. Legal Traditions of the World. Oxford: Oxford University Press.

2 As examples, consider the earliest constitution, that of (Western) Samoa: "WHEREAS the Leaders of Western Samoa have declared that Western Samoa should be an Independent State based on Christian principles and Samoan custom and tradition;" (Preamble), and that of the most recently independent among the larger states, Vanuatu: "WE the people of Vanuatu... HEREBY proclaim the establishment of the united and free Republic of Vanuatu founded on traditional Melanesian values, faith in God, and Christian principles..." (Preamble). There is of course much more to constitutional interpretation than Preambles; the point here is the inspirational role of these two basic aspirations. Note the difference in the very recent (1997) Constitution of Fiji Islands: it protects, in an elaborate way, indigenous Fijian 'interests' rather than values, within a multicultural framework (Section 6: Compact).

3 Von Clausewitz wrote of the theory of war, at the turn of the 19th century, urging that war be considered 'the continuation of politics by other means'. This was 'true war', what soldiers should train for and armies be prepared for. 'Real war' - looting, raiding, massacres, and so on, what today is called irregular warfare - should be abandoned by civilised military traditions. See Keegan, J. 1993. The Transformation of Warfare. Toronto: Key Porter Books.

4 The village authority could be a 'chief', as in Micronesia, Polynesia, and Vanuatu, most of Solomon Islands, and the coastal and island regions of PNG, or the 'big men' or something like a council, in the rest of Melanesia. I do not mean to imply that identifying exactly who has the requisite authority is easy, even where chiefly status is recognised. Nor indeed is the 'recognition' of chiefly status always unproblematic. In Vanuatu the status appears to have evolved in response to the need to interact formally with outsiders, and now to have specialised in adjudication (as opposed to leadership more generally).

Bolton, L. 1999. Chief Willie Bongmatur Maldo and the Incorporation of Chiefs into the Vanuatu State. Discussion Paper No. 99/2 of the State, Society, and Governance in Melanesia Project. Canberra: Australian National University, pp 4, 8 \& 11.

5 Note that the operation of custom is nonetheless subject to the influence of men whose local power is sometimes due to legal form - like being police officers, civil servants, or members of Parliament (and, in a nice demonstration of how custom and that form influence each other, they are men rather than women).

6 Le Tagaloa Pita et al v Attorney-General, Unreported, Court of Appeal of Western Samoa CA 7/95, December 1995.

7 For examples of the first, invoking the common law of confessions, see State v Joseph Maino [1977] PNGLR 216 and State v Evertius and Kundi [1985] PNGLR 109. For the second, where 'negligence' is the cause of action despite the nature of the police acts complained of, see, for example, Helen Jack v Karani and Papua New Guinea [1992] PNGLR 391 (assassination) and Komaip Trading $v$ Waugulo and Papua New Guinea [1995] PNGLR 165 (shop-burning). 
8 I discuss some implications of this strain in Fraser, I. 2000. Legal Theory in Melanesia: Pluralism? Dualism? Pluralism long Dualism? Journal of South Pacific Law Vol. 3 (http://www.vanuatu.usp.ac.fj/journal_splaw/articles/Fraserl.htm Accessed 19/9/02).

9 See, for an overview, Garrett, J. 1982. To Live Among The Stars: Christian Origins in Oceania. Geneva \& Suva: World Council of Churches \& USP. In particular, see pp 72-78 (Tonga), pp 102-114 (Fiji), pp 121-129 (Samoa), pp 171-185 (Vanuatu), pp 241-243 (Papua) and pp 298-300 (Solomon Islands).

10 What Ronald Dworkin calls a concept, rather than a conception: the expression in a particular context of a principle, rather than the precise term with which the appropriate ruling is expressed. He had in mind contrasts like a right to liberty in one's private life (the concept) and the deregulation of condom sales (the conception). See, for example, Dworkin, R. 1977. Taking Rights Seriously. Cambridge, Mass: Harvard University Press.

11 One can - of course! - debate issues of emphasis here; traditional beliefs, for example, would usually have to redefine who counts as 'one of us' before they could be said to feature love of one's neighbours. Suffice it to say that Christianity is as capable as any other religion of supporting xenophobia. The faithful interpret their own religions fairly freely - as lawyers do their constitutions. Not one word of the US Bill of Rights was changed, for instance, between when segregation was 'constitutional' and when it became 'unconstitutional'.

12 That way could be opposition and resistance, of course, as long as these seem viable options. Consider the spread of 'fundamentalist' versions of Christianity, Islam, Judaism, and Hinduism, as well as the Pacific movements, perhaps precursors to cargo cults, which featured the destruction of goods, animals, and homes, in the expectation of a messianic deliverance to the intact old ways. (There were such movements in North America and South Africa as well.)

13 In other words, it can thus allow 'a new politics', characterising the current post-modern era, in which one's personal identity becomes identified with one's political convictions. This is as contrasted to the distinction of personality and politics characterising modernity, and to the tying of personality to politics through kinship characterising traditional times. One factor promoting it is a focus on issues rather than ethnic or personal association. See, further, Larmour, P. 1994. Is there a 'New' Politics in the South Pacific? In vom Busch, W. et al, (eds.) New Politics in the South Pacific. Raratonga \& Suva: Institute for Pacific Studies. 3-15 at pp 4-6.

14 The best-known example of this thinking - though expressed long after constitutionframing - is Narakobi, B. 1989. Lo Bilong Yumi Yet. Papua New Guinea: Melanesian Institute.

15 See Newton Cain, T. elsewhere in this volume.

16 For a contemporary overview, see the special issue of Stanford Law Review, Vol 36, 1984. For a more recent version in the British tradition, see Waldron, J. 1993. A Rights-Based Critique of Constitutional Rights. Oxford Journal of Legal Studies 13:18-51.

17 See, for the instigation of this reaction, Delgado, R. 1987. The Ethereal Scholar: Does Critical Legal Studies Have What Minorities Want? Harvard Civil Rights-Civil Liberties Review 22:301. 
18 I discuss the potentially great ramifications of the UK's effective adoption of the European Convention on Human Rights as domestic legislation in Fraser, I. 2000. The Cradle Will Rock: The South Pacific and the Coming Revolution in English Common Law. Paper presented at ALTA Conference, July 2000 (Canberra). It will soon be impossible for Pacific courts to invoke contemporary English case law without discussing human rights.

19 This could mirror what seems to be the distinction already established in popular thinking: that 'politics' is national and 'custom' is local; and only the political power gained in the latter sphere is wholly legitimate. Huffer, E. and Molisa, G. 1999. Governance in Vanuatu: In Search of the Nakamal Way. Discussion Paper No. 99/4 of the State, Society, and Governance in Melanesia Project. Canberra: Australian National University.

This work was based on a survey of people conducted in November 1997. There is a maxim in American politics: 'all politics is local' - the political issues that actually motivate voters are the local issues.

20 “[P]aramount chiefs are good to Westernise with," quote Lindstrom, L. and White, G. 1997. Chiefs Today. In Lindstrom, L. and White,G. (eds.) Chiefs Today: Traditional Pacific Leadership and the Postcolonial State Stanford, California: Stanford University Press at $\mathrm{p}$ 18. Their point is the importance of not seeing 'chiefs' as simply the rearguard of retreating tradition. See also White, G. The Discourse of Chiefs: Notes on a Melanesian Society in the same volume, with reference to Solomon Islands. 